\title{
Perbedaan Myocardial Performance Index Ventrikel Kiri pada Remaja Obes dengan dan tanpa Sindrom Metabolik
}

\author{
Riri Adriana, Dwi Prasetyo, Sri Endah Rahayuningsih \\ Departemen Ilmu Kesehatan Anak Fakultas Kedokteran Universitas Padjadjaran/Rumah Sakit Dr. Hasan Sadikin, Bandung
}

\begin{abstract}
Latar belakang. Myocardial performance index (MPI) merupakan pemeriksaan ekokardiografi yang lebih sensitif dalam mendeteksi disfungsi diastolik ventrikel kiri.

Tujuan. Menentukan perbedaan MPI ventrikel kiri pada remaja obes dengan SM, obes tanpa SM, dan non-obes.

Metode. Penelitian analitik potong silang pada 30 remaja obes (dengan dan tanpa sindrom metabolik) dan 30 non-obes usia 10-19 tahun yang memenuhi kriteria inklusi. Penelitian dilakukan di Instalasi Pelayanan Jantung RSUP Dr. Hasan Sadikin Bandung selama November 2014-Januari 2015. Pemeriksaan MPI dilakukan dengan alat ekokardiografi GE tipe Vivid 7. Dilakukan pemeriksaan kolesterol total, trigliserida, LDL, HDL, dan gula darah menggunakan alat Architect. Kriteria SM ditegakkan apabila terpenuhi dua dari parameter trigliserida $>150 \mathrm{mg} / \mathrm{dL}, \mathrm{HDL}<40 \mathrm{mg} / \mathrm{dL}$, GDP $>100 \mathrm{mg} / \mathrm{dL}$, hipertensi, dan kegemukan sentral. Perbedaan nilai MPI antara remaja obes dengan SM, obes tanpa SM, dan remaja non-obes ditentukan dengan uji ANOVA satu arah. Hasil. Nilai MPI pada remaja obes dengan SM, obes tanpa SM, dan remaja non-obes adalah 0,35, 0,36, dan 0,36 ( $\mathrm{p}=0,778$ ). Kesimpulan. Tidak terdapat perbedaan nilai MPI pada remaja obes dengan SM, obes tanpa SM, dan remaja non-obes. Sari Pediatri 2015;17(4):307-11.
\end{abstract}

Kata kunci: myocardial performance index-tissue Doppler imaging, remaja obes, sindrom metabolik

\section{The Differences of Left Ventricle Myocardial performance index in Obese Adolescents with and without Metabolic Syndrome}

\author{
Riri Adriana, Dwi Prasetyo, Sri Endah Rahayuningsih
}

\begin{abstract}
Background. Myocardial performance index (MPI) is a more sensitive echocardiography examination in detecting left ventricular diastolic dysfunction compared to conventional echocardiography.

Objectives. To determine the differences of left ventricle MPI in obese adolescents with MS, obese adolescents without MS, and non-obese adolescents.

Method. The research used a cross-sectional analytical design on 30 obese adolescents (with and without MS) with central obesity and 30 non-obese adolescents aged 10-19 years old. The study was carried out in the Cardiac Care Unit of Dr. Hasan Sadikin Hospital. Bandung from November 2014 to January 2015. Myocardial performance index was measured with Vivid 7 echocardiography. Total cholesterol, triglyceride, LDL, HDL, and fasting blood glucose were measured with Architect. One way ANOVA was used to determine the differences between the groups.

Results. The MPI of obese adolescents with MS, obese adolescents without MS, and non-obese adolescents were $0.35,0.36$, dan 0.36 ( $\mathrm{p}=0.778)$.

Conclusion. The MPI of obese adolescents with MS, obese adolescents without MS, and non-obese adolescents showed no differences. Sari Pediatri 2015;17(4):307-11.
\end{abstract}

Keywords: obese adolescents, metabolic syndrome, myocardial performance index-tissue Doppler imaging

Alamat korespondensi: Dr. Sri Endah Rahayuningsih, dr.,SpA(K). Departemen Ilmu Kesehatan Anak Fakultas Kedokteran Universitas Padjadjaran/Rumah Sakit Dr. Hasan Sadikin Bandung. Jl. Pasteur No. 38 Bandung 40163. Telp.022-3035957. Email : endah.perkani@gmail.com 
Riri Adriana dkk: Perbedaan MPI ventrikel kiri pada remaja obes dengan dan tanpa sindrom metabolik

M asa remaja merupakan periode kritis terjadinya obesitas. Delapan puluh persen remaja obes akan berkembang menjadi dewasa obes. ${ }^{1}$ Pada remaja di Amerika Serikat, prevalensi obesitas mengalami peningkatan 5,1\% pada tahun 1980 menjadi $21 \%$ pada tahun $2010 .^{2}$ Obesitas, terutama obesitas sentral, merupakan faktor risiko sindrom metabolik (SM). ${ }^{3}$ Laporan National cholesterol education program adults treatment panel III (NCEP-ATP III) menunjukkan peningkatan 4,2\% prevalensi SM pada remaja obes pada periode 1988-1992 menjadi 6,4\% pada periode $1999-2000 .{ }^{4}$ Di Indonesia, prevalensi SM remaja obes bervariasi. Penelitian di Jakarta dilaporkan prevalensi SM remaja obes laki-laki 19,14\% dan perempuan 10,63\%.5 Penelitian lain di Jawa Tengah dilaporkan prevalensi SM remaja obes 31,6\%. ${ }^{6}$ Obes dengan SM memiliki risiko 3 kali lebih besar untuk mengalami serangan jantung dan strok serta 5 kali lebih besar untuk mengalami diabetes melitus tipe $2{ }^{7}$

Gangguan fungsi ventrikel yang berupa disfungsi diastolik ventrikel kiri merupakan gangguan jantung yang pertama kali terjadi pada keadaan obesitas dengan SM, tetapi sering kali tidak terdeteksi karena bersifat subklinis. ${ }^{8}$ Diagnosis disfungsi diastolik ventrikel dapat dinilai menggunakan Myocardial performance index Tissue Doppler Imaging (MPI TDI) dengan menghitung indeks Tei.

Penelitian pada remaja ditunjukkan perbedaan bermakna nilai MPI ventrikel kiri remaja non-obes dan obes. ${ }^{9} 10$ Penelitian pada orang dewasa dilaporkan nilai MPI ventrikel kiri dewasa non-obes dengan SM lebih meningkat dibandingkan dewasa non-obes tanpa SM. Peningkatan nilai MPI menunjukkan fungsi diastolik ventrikel kiri yang menurun. ${ }^{11}$ Penelitian lain melaporkan nilai MPI ventrikel kiri pada dewasa obes dengan dan tanpa SM mengalami peningkatan dan berbeda secara bermakna dengan dewasa non-obes. ${ }^{12}$

Deteksi dini disfungsi ventrikel kiri pada remaja obes dengan atau tanpa SM perlu dilakukan guna mencegah kelainan kardiovaskular lebih lanjut sehingga diharapkan dapat menurunkan tingkat morbiditas dan mortalitas akibat SM. Oleh karena itu, tujuan penelitian ini adalah menentukan perbedaan MPI ventrikel kiri pada remaja obes dengan SM, obes tanpa SM, dan non-obes.

\section{Metode}

Penelitian analitik komparatif dengan rancangan potong silang yang dilakukan sejak bulan November
2014 hingga Januari 2015. Subjek penelitian adalah 30 remaja obes dan 30 non-obes sebagai kelompok kontrol yang dipilih secara purposive sampling yang berasal dari sekolah dasar (SD), sekolah menengah pertama (SMP), dan sekolah menengah atas (SMA) Angkasa Kotamadya Bandung. Kriteria inklusi adalah remaja usia 10-19 tahun yang memenuhi kriteria obesitas menurut WHO 2007 serta kriteria kegemukan sentral yang ditandai dengan rasio lingkar pinggangtinggi badan $\geq 0,5$. Kriteria eksklusi adalah hipertensi, diabetes melitus, hiperkolesterolemia familial, subjek dengan kelainan jantung bawaan, sindrom Down, atau memiliki kelainan bawaan lain.

Data subjek penelitian diperoleh dengan kuesioner. Pengukuran berat badan dan tinggi badan dilakukan dengan alat ukur timbangan dan stadiometer Seca. Pengukuran lingkar pinggang dilakukan dengan mengukur lingkar yang terletak di atas krista iliaka pada saat akhir ekspirasi dengan menggunakan tali pengukur yang tidak lentur. Semua subjek diperiksa kolesterol total, trigliserida, LDL, HDL, dan gula darah dengan alat Architect yang diperiksa setelah subjek puasa minimal 8 jam. Kriteria sindrom metabolik ditegakkan apabila terpenuhi dua dari parameter berikut, yaitu nilai trigliserida $>150 \mathrm{mg} / \mathrm{dL}, \mathrm{HDL}<40 \mathrm{mg} / \mathrm{dL}$, GDP $>100 \mathrm{mg} / \mathrm{dL}$, hipertensi, dan kegemukan sentral. ${ }^{7}$

Pemeriksaan fungsi ventrikel kiri dengan menghitung MPI dilakukan dengan alat ekokardiografi GE tipe Vivid 7 oleh seorang konsultan pediatrik kardiologi dan teknisi ekokardiografi. Pengukuran MPI TDI dengan Indeks Tei didapatkan dengan menggabungkan nilai isovolumetric contraction time (ICT) dan isovolumetric relaxation time (IRT) dibagi dengan ejection time (ET). Myocardial performance index Tissue Doppler Imaging mampu mendeteksi kelainan fungsi ventrikel yang tidak terdeteksi sebelumnya oleh pemeriksaan ekokardiografi konvensional seperti M-Mode ekokardiografi karena tidak dipengaruhi oleh geometri ventrikel yang sering kali berubah pada keadaan obesitas. ${ }^{13,14}$ Surat persetujuan (informed consent) penelitian ditandatangani subjek dan orangtua setelah diberikan penjelasan.

Semua data yang diperoleh dicatat dan ditabulasi. Dalam melakukan analisis data, terlebih dahulu dilakukan uji normalitas data dengan Shapiro Wilk. Uji normalitas data menunjukkan data berdistribusi normal sehingga uji ANOVA satu arah digunakan untuk mengetahui perbedaan MPI ventrikel kiri pada remaja obes dengan SM, obes tanpa SM, dan non-obes. 


\section{Hasil}

Selama periode penelitian didapatkan 30 remaja nonobes dan 30 obes, terdiri atas 13 remaja tanpa SM dan 17 remaja dengan SM. Kelompok remaja non-obes tidak ada yang memenuhi kriteria kegemukan sentral dan tidak ada yang memiliki SM (Tabel 1).

Nilai MPI pada ketiga kelompok tidak menunjukkan perbedaan bermakna (Tabel 2).

\section{Pembahasan}

Kami mendapatkan 17 dari 30 remaja obes dengan kegemukan sentral mengalami SM. Usia rerata remaja perbedaan nilai MPI di antara ketiga kelompok.

Gangguan kardiovaskular yang terjadi pada SM berhubungan dengan terbentuknya kegemukan sentral/abdomen. Peningkatan lemak viseral abdomen dapat menyebabkan beberapa mekanisme gangguan kardiovaskular dan abnormalitas metabolisme pada pasien obesitas. Beberapa mekanisme di antaranya ${ }^{15}$ (1) paparan hepar oleh peningkatan asam lemak bebas akan mengakibatkan keadaan hiperinsulinemia, intoleransi glukosa (peningkatan produksi glukosa oleh hepar) dan hipertrigliseridemia (peningkatan sekresi VLDL apolipoprotein B., (2) lemak viseral abdomen merupakan organ endokrin yang mampu memproduksi adipokin (sitokin) seperti IL-6 dan TNFyang berperan terhadap resistensi insulin, keadaan proinflamasi, protrombosis, dan prohipertensi, (3)

Tabel 1. Karakteristik subjek penelitian

\begin{tabular}{lccc}
\hline Karakteristik & $\begin{array}{c}\text { Obes dengan sindrom } \\
\text { metabolik }(\mathrm{N}=17)\end{array}$ & $\begin{array}{c}\text { Obes tanpa sindrom } \\
\text { metabolik }(\mathrm{N}=13)\end{array}$ & $\begin{array}{c}\text { Non-obes } \\
(\mathrm{N}=30)\end{array}$ \\
\hline $\begin{array}{c}\text { Usia (tahun) } \\
\text { Rerata }(\mathrm{SB})\end{array}$ & $14,38(3,21)$ & $13,23(3,27)$ & $14.23(2,75)$ \\
$\begin{array}{c}\text { Jenis kelamin } \\
\text { Laki-laki }\end{array}$ & 9 & 6 & 9 \\
$\quad$ Perempuan & 8 & 7 & 21 \\
LP/TB* & & & \\
$\quad$ Rerata (SB) & $0,62(0,05)$ & $0,62(0,04)$ & $0,50(0,04)$ \\
Pendidikan & 3 & 6 & 5 \\
SD & 5 & 3 & 15 \\
SMP & 9 & 4 & 10 \\
SMA & 5 & & \\
\hline
\end{tabular}

Keterangan: SB: simpang baku $\quad{ }^{*} \mathrm{LP}=$ lingkar perut, $\mathrm{TB}=$ tinggi badan

Tabel 2. Perbedaan MPI ventrikel kiri pada kelompok obes dengan dan tanpa sindrom metabolik dan non-obes

\begin{tabular}{|c|c|c|c|c|}
\hline & \multicolumn{3}{|c|}{ Status gizi } & \multirow[b]{2}{*}{$\mathrm{p}$} \\
\hline & $\begin{array}{l}\text { Obes dengan sindrom metabolik } \\
\qquad(\mathrm{N}=17)\end{array}$ & $\begin{array}{l}\text { Obes tanpa sindrom metabolik } \\
\qquad(\mathrm{N}=13)\end{array}$ & Non-obes & \\
\hline MPI & $0,35(0,10)$ & $0,36(0,06)$ & $0,36(0,05)$ & 0,778 \\
\hline
\end{tabular}

Keterangan: p ANOVA bermakna bila $<0,05$

obes dengan SM adalah 14 tahun, lebih banyak didapatkan pada remaja laki-laki dengan tingkat pendidikan SMA. Pada kelompok remaja non-obes tidak ada yang mengalami SM. Pada tiap kelompok tidak didapatkan hipertensi. Fungsi ventrikel kiri yang diperiksakan dengan MPI masih berada dalam batas normal, baik pada kelompok remaja obes dengan SM, obes tanpa SM, dan non-obes. Tidak terdapat lemak viseral abdomen berhubungan dengan akumulasi lemak jantung mengakibatkan terbentuknya lemak epikardial. Peningkatan kolesterol total, trigliserida, dan gula darah kemudian akan menyebabkan keadaan cardiomyopathy of obesity. ${ }^{16-18}$

Berdasarkan teori tersebut seharusnya terdapat hubungan antara sindrom metabolik dan disfungsi ventrikel kiri yang diperiksa dengan MPI, tetapi kami 
Riri Adriana dkk: Perbedaan MPI ventrikel kiri pada remaja obes dengan dan tanpa sindrom metabolik

mendapatkan sebaliknya. Tidak terdapat perbedaan nilai MPI ventrikel kiri pada remaja obes dengan SM, obes tanpa SM, dan non-obes. Kemungkinan karena metode potong lintang yang digunakan sehingga durasi obesitas tidak diketahui. Beberapa penelitian menemukan bahwa risiko penyakit kardiovaskular terkait obesitas tidak hanya bergantung pada derajat obesitas, tetapi juga pada durasi obesitas. Pemeriksaan gangguan fungsi ventrikel kiri dengan ekokardiografi konvensional, dengan mengukur left ventricular end diastolic diameter index (LVEDd index), mengalami penurunan pada subjek dengan durasi obesitas lebih dari 15 tahun. Penurunan fungsi ventrikel kiri tersebut tidak didapatkan pada subjek dengan durasi obesitas kurang dari 15 tahun. ${ }^{19}$

Penelitian kami merupakan penelitian pertama yang bertujuan mengetahui perbedaan fungsi diastolik ventrikel kiri yang diperiksa menggunakan MPI TDI pada remaja obes dengan dan tanpa SM. Penelitian sebelumnya, pada anak mengenai fungsi ventrikel yang diperiksakan dengan MPITDI hanya membandingkan anak gizi normal dengan obesitas tanpa menganalisis keadaan SM. Penelitian terhadap 20 orang anak obesitas (usia 8-18 tahun) dengan tekanan darah normal melaporkan perbedaan bermakna nilai MPI TDI ventrikel kiri pada anak gizi normal dengan obesitas. ${ }^{9}$ Penelitian lain terhadap 25 anak gizi normal, 25 anak obesitas tanpa hipertensi, dan 25 anak obesitas dengan hipertensi melaporkan bahwa nilai MPI TDI meningkat pada anak obesitas tanpa dan dengan hipertensi. ${ }^{10}$

Pada penelitian orang dewasa dilaporkan nilai MPI ventrikel kiri dewasa non-obes dengan SM lebih meningkat dibandingkan dewasa non-obes tanpa SM. Peningkatan nilai MPI menunjukkan fungsi diastolik ventrikel kiri yang menurun. ${ }^{11}$ Penelitian lain melaporkan nilai MPI ventrikel kiri pada dewasa obes dengan dan tanpa SM mengalami peningkatan dan berbeda secara bermakna dengan dewasa non-obes. ${ }^{12}$

\section{Kesimpulan}

Kami tidak mendapatkan perbedaan MPI pada remaja obes dengan dan tanpa SM, Kemungkinan penyebab adalah jumlah sampel penelitian yang sedikit karena keterbatasan waktu dan dana. Berdasarkan nilai power test yang rendah disarankan besar sampel minimal untuk taraf signifikansi 5\% dan power test $80 \%$ adalah minimal 502 sampel per-kelompok.

Disarankan dilakukan penelitian lain yang serupa dalam bentuk kohort dengan jumlah subjek yang lebih besar dan dengan menganalisis durasi obesitas.

\section{Daftar pustaka}

1. Reilly JJ, Armstrong J, Dorosty AR, Emmett PM, Ness A, Rogers I, dkk. Early life risk factors for obesity in childhood: cohort study. BMJ 2005:1-7.

2. Centers for Disease Control and Prevention . Childhood obesity facts [document on the Internet]. 2014. Diperbaharui 24 Mei 2013; diunduh 06 Juni 2014. Didapat dari: www.cdc.gov/healthyyouth/obesity/facts.htm.

3. Rizzo AC, Goldberg TB, Silva CC, Kurokawa CS, Nunes HR, Corrente JE. Metabolic syndrome risk factors in overweight, obes, and extremely obes Brazilian adolescents. Nutr J 2013;12:1-7.

4. Duncan GE, Li SM, Zhou XH. Prevalance and trends of a metabolic syndrome phenotype among U.S adolescentss 1999-2000. Diabetes Care 2004;27:2438-43.

5. Sibarani RP, Rudijanto A, Dekker J, Hiene RJ. The petai china study: metabolic syndrome among obes indonesian Chinese adolescentss. Indonesia J Intern Med 2006;38:142-4.

6. Mexitalia M, Utari A, Sakundarno M, Yamauchi T, Subagio HW, Soemantri A. Sindrom metabolik pada remaja obesitas. Met Indones 2009;43:300-6.

7. International Diabetes Federation. Metabolic syndrome in children and adolescents. Belgium. International Diabetes Federation; 2007.

8. Ghanem S, Mostafa M, Ayad S. Early echocardiography abnormalities in obes children and adolescents and reversibility of these abnormalities after significant weight reduction. J Saudi Heart Assoc 2010;22:13-8.

9. Cetin MCM, Yildirimer M, Kizilyildiz BS, Deveci M, Coskun S. Tissue doppler echocardiography for evaluating left ventricular functions in obes children. Dicle Med J 2013;40:9-14.

10. Levent E, Goksen D, Ozyurek AR, Darcan S, Coker M. Usefulness of the Myocardial performance index for assessing ventricular function in obes pediatric patients. Turkish J Pediatr 2005;47:34-8.

11. Voulgari C, Moyssakis I, Papazafiropoulou A, Perrea D, Kyriaki D, Katsilambros N, dkk. The impact of metabolic syndrome on left ventricular myocardial performance index. Diabetes Metab Res Rev 2010;26:121-7.

12. Koc FMT, Kaya C, Kayrak M, Yazici M, Karabag T, 
Vatankulu MA. Diastolic functions and Myocardial performance index $\mathrm{n}$ obes patients with or without metabolic syndrome: a tissue Doppler study. Arch Turk Soc Cardiol 2010;38:400-4.

13. Solomon $S$, penyunting. Essential echocardiography a practical handbook with dvd. New Jersey: Human Press inc; 2007.

14. Lakoumentas JA, Panou FK, Kotseroglou VK, Aggeli KI, Harbis PK. The Tei index of myocardial performance: applications in cardiology. Hellenic J Cardiol 2005;46:52-8.

15. Despres JP, Bergeron J, Pibarot P, Mathieu P, Larose E. Abdominal obesity and the metabolic syndrome: Contribution to global cardiometabolic risk. Arterioscler Thromb Vasc Biol 2008;28:1039-49.
16. Iacobellis G, Bianco AC. Epicardial adipose tissue: emerging physiological, pathophysiological and clinical features. TEM 2011;22:450-7.

17. Iozzo P. Myocardial, perivascular, and epicardial fat. Diabetes Care 2011;34:S371-9.

18. Turfan M, Akyel A, Bolayir HA, Vatankulu MA, Akturk M, Yetkin I, dkk. Correlation of the Myocardial performance index with plasma B-type natriuretic peptide levels in type 2 diabetes mellitus and impaired glucose tolerance. Kardiologia Polska 2012;70:55662.

19. Nakajima T, Fujioka S, Tokunaga K, Hirobe K, Matsuzawa Y, Tarui S. Noninvasive study of left ventricular performance in obes patients: influence of duration of obesity. Circulation 1985;71:481-6. 